\title{
Persistent Spectral Hole Burning in Samarium and Aluminum Codoped Silica Films Prepared by RF Sputtering
}

\author{
Toshiro FUTAGAMI, Masayuki KAMEI, Itaru YASUI, Yuzo SHIGESATO*, \\ Naoki SUGIMOTO** and Yasuo HAYASHI** \\ Institute of Industrial Science, The University of Tokyo, 7-22-1, Roppongi, Minato-ku, Tokyo 106-8558 \\ *College of Science and Engineering, Aoyama Gakuin University, 6-16-1, Chitosedai, Setagaya-ku, Tokyo 157-8572 \\ **Research Center, Asahi Glass Co., Ltd., 1150, Hazawa-cho, Kanagawa-ku, Yokohama-shi, Kanagawa 221-8755 \\ RF スパッタリングにより作製したサマリウム・アルミニウム含有シリカ薄膜の \\ 永続的スペクトルホールバーニング \\ 二上俊郎・亀井雅之・安井 至・重里有三*。杉本直樹**。林 泰夫** \\ 東京大学生産技術研究所, 106-8558 東京都港区六本木7-22-1 \\ *青山学院大学理工学部化学科, 157-8572 東京都世田谷区干歳台6-16-1 \\ **旭硝子(侏)中央研究所, 221-8755 神奈川県横浜市神奈川区羽沢町1150
}

\begin{abstract}
We observed persistent spectral hole burning in the excitation spectra of a $\mathrm{Sm}$ and Al codoped $\mathrm{SiO}_{2}$ thin film at 77 and $180 \mathrm{~K}$. The film was prepared from $\mathrm{Sm}, \mathrm{Al}$ and $\mathrm{SiO}_{2}$ by $\mathrm{RF}$ co-sputtering at a substrate temperature of $300^{\circ} \mathrm{C}$. At $77 \mathrm{~K}$, the width of the hole was $2 \mathrm{~cm}^{-1}$ with a depth of $4 \%$ of the total intensity, while at $180 \mathrm{~K}$, they were measured at $10 \mathrm{~cm}^{-1}$ and $1 \%$ of the total intensity. The optical absorption and photoluminescence properties of the deposited films were changed by the use of elemental Sm and Al instead of $\mathrm{Sm}_{2} \mathrm{O}_{3}$ and $\mathrm{Al}_{2} \mathrm{O}_{3}$. [Received December 16, 1998; Accepted March 26, 1999]
\end{abstract}

Key-words : Thin film, RF sputtering, Persistent spectral hole burning, Photoluminescence, Samarium, Aluminum, Aluminosilicate, Silicon oxide

\section{Introduction}

Reports of persistent spectral hole burning (PSHB) at room temperature in fluoride single crystals, ${ }^{1)}$ and then the subsequent discovery of PSHB in glass materials ${ }^{2}$ ) have spurred an unprecedented effort by many research groups to explore both the physical mechanism underlying this phenomenon and its technological potential for optical memories. Glasses have the potential to be more suitable for high-density memory device than single crystals because of their wide inhomogeneous width, high transparency and easy mass production. To date, however, these materials have only been prepared in bulk form by conventional glass-melting techniques ${ }^{2}$ or by sol-gel processes.3)-6) Preparation of thin films of suitable materials is of significant importance. The only report of PSHB in thin films at high temperature was by Asatsuma et al. ${ }^{7)}$ who observed it in Sr-halide crystal films. We report on our observation of PSHB in a $\mathrm{Sm}^{2+}$-doped amorphous thin film at a temperature of $77 \mathrm{~K}$ and above.

\section{Experimental}

$\mathrm{Sm}$ and $\mathrm{Al}$ codoped $\mathrm{SiO}_{2}$ films were prepared using an $\mathrm{RF}$ magnetron sputtering apparatus (Anelva, Model SPF$332 \mathrm{H}$ ) under the conditions listed in Table 1. A Sm chip

Table 1. Sputtering Condition

\begin{tabular}{lc}
\hline Sputtering gas & $\mathrm{Ar}$ (purity 99.999\%) \\
Gas pressure & $1.0 \mathrm{~Pa}$ \\
RF power & $200 \mathrm{~W}$ \\
Substrate material & Fused silica \\
Substrate temperature & $300{ }^{\circ} \mathrm{C}$ \\
Substrate-target distance & $50 \mathrm{~mm}$ \\
Target & $\left(\mathrm{Sm}+\mathrm{Al}+\mathrm{SiO}_{2}\right)$ for $\mathrm{S} 1-\mathrm{S} 5$ or \\
& $\left(\mathrm{Sm}_{2} \mathrm{O}_{3}+\mathrm{Al}_{2} \mathrm{O}_{3}+\mathrm{SiO}_{2}\right)$ for S-6 \\
Sputtering time & $5 \mathrm{~h}$ \\
\hline
\end{tabular}

$\left(5 \times 5 \times 1 \mathrm{~mm}^{3}\right.$, purity $\left.99.9 \%\right)$ was placed on an Al plate ( $\$ 20 \mathrm{~mm} \times 1 \mathrm{mmt}$, purity $99.99 \%$ ) which was placed on a $\mathrm{SiO}_{2}$ (purity 99.99\%) target of 3 inches in diameter. Then the target $\left(\mathrm{Sm}+\mathrm{Al}+\mathrm{SiO}_{2}\right)$ was co-sputtered to deposit films S1-S5, as listed in Table 1. The Sm and Al concentrations of the films were varied by slightly changing the positions of the Sm chip and the Al plate around the center of the $\mathrm{SiO}_{2}$ target. For comparison, $\mathrm{Sm}_{2} \mathrm{O}_{3}$ chips $(5 \times 5 \times 1$ $\mathrm{mm}^{3}, 3$ pcs. $)$ and $\mathrm{Al}_{2} \mathrm{O}_{3}$ chips $\left(5 \times 5 \times 1 \mathrm{~mm}^{3}, 6\right.$ pcs. $)$ were used for film S6 instead of the Sm chip and the Al plate, respectively.

The structure of the films was determined by X-ray diffraction analysis (Rigaku, Model RINT2100). The composition of the films was determined by X-ray photoelectron spectroscopy (XPS) using monochromatic AlK( radiation (Physical Electronics, Model 5500). Film thickness was measured with a stylus-type instrument (Sloan, Model Dektak3). The optical absorption spectra of the films were measured in the range of $300-800 \mathrm{~nm}$ with a spectrometer (Shimadzu, Model UV-3100PC). The photoluminescence (PL) spectra excited by 400-nm light were measured in the range of 550-850 $\mathrm{nm}$ with a band-width of $1.5 \mathrm{~nm}$ using a spectrophotometer (Shimadzu, Model RF-5300PC) at room temperature. Hole-burning experiments were carried out using an Ar-ion laser pumped DCM dye laser with a linewidth of $1.3 \mathrm{~cm}^{-1}$ at 77, 180 and $300 \mathrm{~K}$. Samples were irradiated using a $683 \mathrm{~nm}$ wavelength of the DCM dye laser operating at $640 \mathrm{~mW} / \mathrm{mm}^{2}$ for $600 \mathrm{~s}$. After irradiation, the excitation spectra were obtained by scanning the output of the DCM dye laser $\left(6 \mathrm{~mW} / \mathrm{mm}^{2}\right)$ and monitoring the ${ }^{5} D_{0} \rightarrow$ ${ }^{7} F_{2}$ emission at $725 \mathrm{~nm}$.

\section{Results and discussion}

All the films deposited in this study were confirmed to be amorphous by X-ray diffraction analysis. The composition and thickness of the deposited films are listed in Table 2. The XPS analysis revealed that the composition of the films 
Table 2. Thickness and Composition of the Deposited Films

\begin{tabular}{ccccc}
\hline Film & Thickness & \multicolumn{3}{c}{ Composition (at. \%) } \\
\cline { 3 - 5 } number & $(\mu \mathrm{m})$ & $\mathrm{Sm}$ & $\mathrm{Al}$ & $\mathrm{Si}$ \\
\hline S-1 & 7.58 & 1.8 & 7.8 & 90.4 \\
S-2 & 5.83 & 2.1 & 13.5 & 84.4 \\
S-3 & 6.38 & 2.3 & 11.5 & 86.2 \\
S-4 & 5.45 & 2.4 & 11.6 & 86.0 \\
S-5 & 5.83 & 16.5 & 8.9 & 77.4 \\
S-6 & 5.83 & 16.5 & 24.5 & 59.0 \\
\hline
\end{tabular}

$\mathrm{S} 1-\mathrm{S} 4$ was in the range of the reported values for bulk materials. ${ }^{3)}$ The color of these films was clear brown with a slightly reddish tinge. The film S5 was dark brown, while the film S6 was transparent with a faint pink tinge. Figure 1 shows the optical absorption spectra for these films. The strong absorption of the films S1-S5 in the range of 300$600 \mathrm{~nm}$ may be due to the $4 f^{6} \rightarrow 4 f^{5} 5 d$ transition of the $\mathrm{Sm}^{2+}$ ions or to defects produced by reduction within the Al-Si-O network. No sharp peaks from the $f-f$ transition of $\mathrm{Sm}^{3+}$ ions or $\mathrm{Sm}^{2+}$ ions were found in these spectra, while two prominent peaks were found in the spectrum of film S6 at 401 and $628 \mathrm{~nm}$, which were attributed to the ${ }^{6} \mathrm{H}_{5 / 2} \rightarrow{ }^{6} P_{3 / 2}$ transition of $\mathrm{Sm}^{3+}$ ions and the ${ }^{7} F_{0} \rightarrow 5 D_{1}$ transition of $\mathrm{Sm}^{2+}$ ions, respectively. These results indicate that reducing conditions are more easily obtained by using elemental Sm and $\mathrm{Al}$ rather than $\mathrm{Sm}_{2} \mathrm{O}_{3}$ and $\mathrm{Al}_{2} \mathrm{O}_{3}$.

Sharp peaks were observed in the PL spectra of all films except film S6, as shown in Fig. 2. The PL lines at 683, 700, $725 \mathrm{~nm}$ were attributed to ${ }^{5} D_{0} \rightarrow{ }^{7} F_{0,1,2}$ transitions of the $\mathrm{Sm}^{2+}$ ions, respectively. No PL lines for $\mathrm{Sm}^{2+}$ were observed in the spectrum of S6, probably because of a lack of absorption for excitation, although the presence of $\mathrm{Sm}^{2+}$ ions was confirmed in the absorption spectrum. On the other hand, weaker peaks were observed for S5, although it had the same Sm concentration as S6. This difference can be attributed to the difference in absorption for excitation. The low PL intensity for S5, compared with those of S1-S4, was due to the absorption of emissions by the $f-d$ transition of $\mathrm{Sm}^{2+}$. S3 had the maximum PL peak intensity at $683 \mathrm{~nm}$, whereas S4 had approximately half the intensity of S3. This result indicates that the PL peak intensity is not dependent on the composition of the films, because both these had roughly the same composition. Further investigations are in

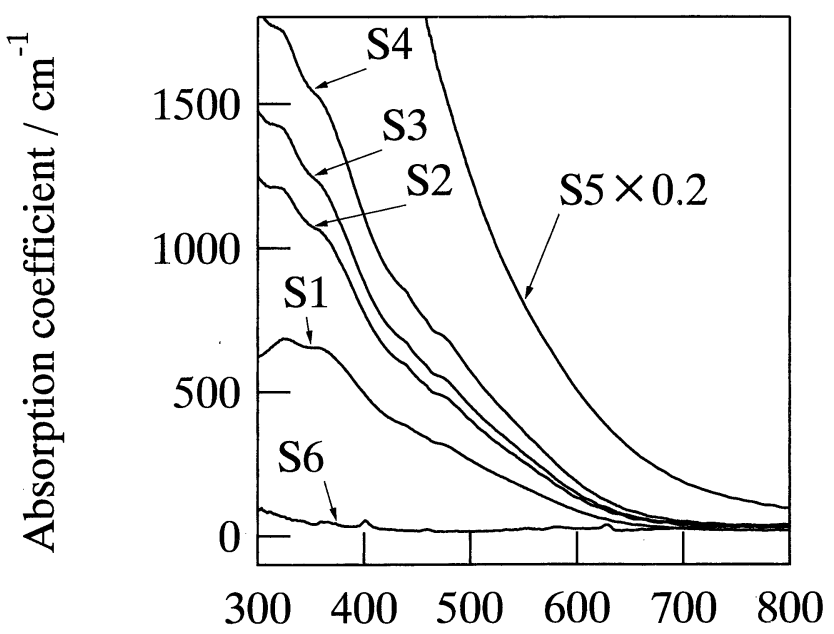

Wavelength / $\mathrm{nm}$

Fig. 1. Optical absorption spectra of $\mathrm{Sm}$ and $\mathrm{Al}$ codoped $\mathrm{SiO}_{2}$ films. The spectrum of S5 is multiplied by a factor of 0.2 . progress to clarify the factors governing the PL intensity. S3 was used for the PSHB experiments because of its high PL intensity. Figure 3 shows the excitation spectra of $\mathrm{Sm}^{2+}$ in the as-deposited film measured at 77, 180 and 300 $\mathrm{K}$ after irradiation with a dye laser. The hole depth decreased as temperature increased. The width and depth of the hole at $77 \mathrm{~K}$ were $2 \mathrm{~cm}^{-1}$ and $4 \%$ of the total intensity, respectively. They were approximately $10 \mathrm{~cm}^{-1}$ and $1 \%$ of the total intensity at $180 \mathrm{~K}$. We could not find a hole clearly at $300 \mathrm{~K}$, because of the small signal to noise ratio in the excitation and hole spectra. Compared with the PSHB of the sol-gel derived $\mathrm{Sm}^{2+}$-doped aluminosilicate glass, ${ }^{3)}$ which was observed to have a depth of $10 \%$ and a width of $15-17$ $\mathrm{cm}^{-1}$ at room temperature, the hole profile of the present film was apparently shallower. For application in the optical data storage at room temperature, deep and narrow holes are required. This difference is the object of the further studies. However, we believe that this PSHB observation is a significant step towards the frequency domain optical

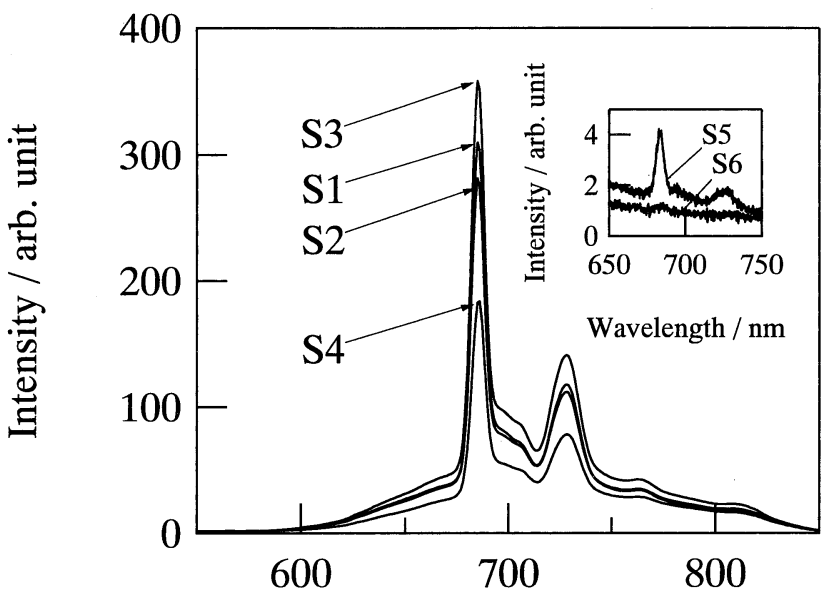

Wavelength / nm

Fig. 2. Photoluminescence spectra, excited at $400 \mathrm{~nm}$, of $\mathrm{Sm}$ and $\mathrm{Al}$ codoped $\mathrm{SiO}_{2}$ films. The spectra of $\mathrm{S} 5$ and $\mathrm{S} 6$ are shown in the insets.

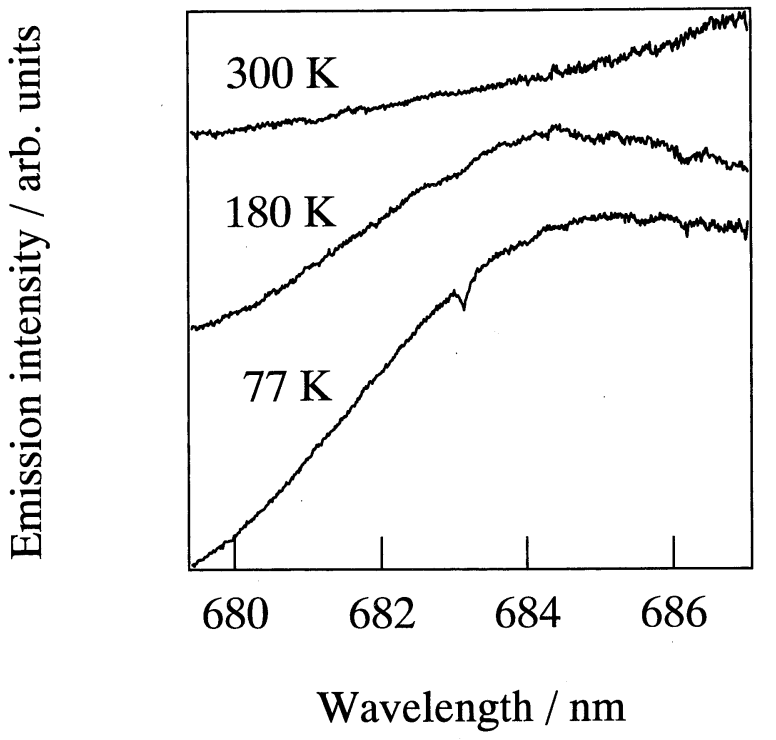

Fig. 3. Excitation spectra of S3 measured at 77, 180, $300 \mathrm{~K}$ monitored at $725 \mathrm{~nm}$ after irradiation at $683 \mathrm{~nm}$. 
storage applications and the sputtering method is the most promising method for fabricating them.

\section{Conclusions}

We observed PSHB at 77 and $180 \mathrm{~K}$, in $\mathrm{Sm}$ and $\mathrm{Al}$ codoped $\mathrm{SiO}_{2}$ thin films deposited from $\mathrm{Sm}, \mathrm{Al}$ and $\mathrm{SiO}_{2}$ by $\mathrm{RF}$ sputtering at a substrate temperature of $300^{\circ} \mathrm{C}$. The optical absorption and photoluminescence properties of the deposited films were affected by the use of elemental $\mathrm{Sm}$ and $\mathrm{Al}$ instead of $\mathrm{Sm}_{2} \mathrm{O}_{3}$ and $\mathrm{Al}_{2} \mathrm{O}_{3}$.

Acknowledgments The authors would like to thank Dr. K. Hirao for his advice and Mr. K. Fujita for his help in measurements of PSHB, both at Kyoto University.

\section{References}

1) R. Jaaniso and H. Bill, Europhys. Lett., 16, 569-74 (1991).

2) K. Hirao, S. Todoroki, D. H. Cho and N. Soga, Opt. Lett., 18, 1586-87 (1993).

3) M. Nogami, Y. Abe, K. Hirao and D. H. Cho, Appl. Phys. Lett., 66, 2952-54 (1995)

4) M. Nogami and Y. Abe, J. Sol-Gel Sci. and Tech., 8, 867-70 (1997).

5) M. Nogami, N. Hayakawa, N. Sugioka and Y. Abe, J. Am. Ceram. Soc., 79, 1257-61 (1996).

6) D. H. Cho, K. Hirao, N. Soga and M. Nogami, J. Non-Cryst. Solids., 215, 192-200 (1997).

7) T. Asatsuma, N. Umezu, Y. Takemoto and M. Kaneko, J. Lumin., 64, 201-05 (1995). 